
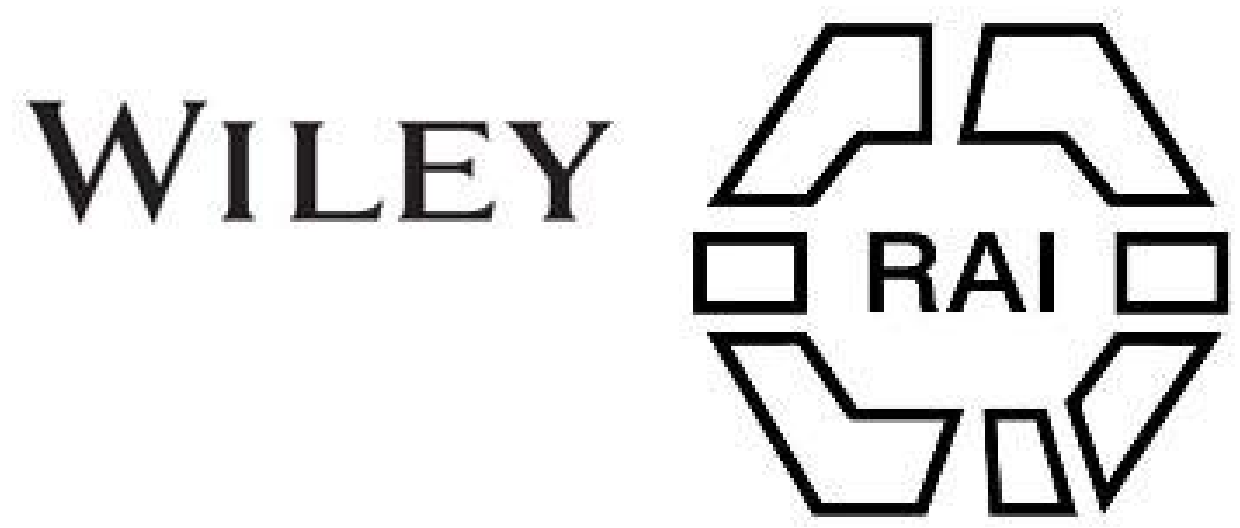

\title{
3. Two Late Bronze Age Urns from East Anglia.
}

\section{Author(s): J. Reid Moir}

Source: Man, Vol. 19 (Jan., 1919), pp. 6-7

Published by: Royal Anthropological Institute of Great Britain and Ireland

Stable URL: http://www.jstor.org/stable/2839916

Accessed: 27-06-2016 03:36 UTC

Your use of the JSTOR archive indicates your acceptance of the Terms \& Conditions of Use, available at

http://about.jstor.org/terms

JSTOR is a not-for-profit service that helps scholars, researchers, and students discover, use, and build upon a wide range of content in a trusted digital archive. We use information technology and tools to increase productivity and facilitate new forms of scholarship. For more information about JSTOR, please contact support@jstor.org.

Wiley, Royal Anthropological Institute of Great Britain and Ireland are collaborating with JSTOR to digitize, preserve and extend access to Man 
predicate by a paraphrase: (a) 'It is the lion that is roaring,' (b) 'What the lion ' is doing is to roar.' Suppose the listener to be in close sympathy with the speaker, the words 'The lion,' or 'He roars,' will often suffice. In presence of the beast itself an interchange of glances between the hunters will be enough, or indeed even less than this.

"It seems clear, then, that speech is a much more complicated thing than mere thought. Besides the content of the statement, command, question, wish, negation, maxim, epigram, or curse that is expressed, there is always involved an unexpressed relation to a listener, which, by a curious paradox, is in practice the decisive factor in determining what words are actually used and the order in which they are arranged.* Nor must it be forgotten that Language is used for concealing or distorting thought (as in lying and boasting) hardly less than for revealing it.

"I fancy that the variations in word-order found in different languages are due less to any deep psychological reason connected with the subject-matter, than primarily to the fact that, since we cannot talk monosyllabically, one element must necessarily come before the other. Some languages plump for 'The lion roars,' others for 'Roars the lion,' when 'roars' is real predicate." $\dagger$

ALAN H. GARDINER.

\section{England : Archæology.}

Moir.

\section{Two Late Bronze Age Urns from East Anglia. By J. Reid Moir.}

The two Late Bronze Age Urns to which this note refers were found respectively near Manningtree, in North Essex, and at Ipswich. The Essex specimen (Fig. 1) is now preserved in the British Museum (Bloomsbury). It was found at Brantham, near Manningtree, and presented to the British Museum in 1914, by Mr. J. R. Keeble, of Brantham Hall. The urn was found at a depth of 3 feet from the surface of the ground, and, so far as is known, did not contain anything of archæological interest. The Suffolk specimen (Fig. 2) is preserved in the Ipswich Museum, and was found at a depth of 3 feet from the surface of the ground, in a field to the north of Hadleigh Road, where the Ipswich Corporation is raising gravel. In one of my periodical visits to this excavation the workman handed me several large pieces of pottery, and indicated exactly where the specimens had been found. It was clear that a digging had been made in the old river-gravel at this spot, which is at the bottom of the main valley, and in close proximity to the canalised River Gipping. The ancient excavation was, at the time of the discovery, still plainly visible in the stratified river deposit. The urn contained a quantity of black, burnt material, amongst which occurred a number oï ossiferous fragments which have been identified by Professor Keith as calcined human bones.

* May it not, then, be said that what is now most required for the progress of linguistic science is the study of comparative Rhetoric?

$\dagger$ Old Egyptian places the verb before the nominative, unlike modern European languages. It agrees with them, however, in making a prepositional or adverbial complement (e.g., "He is there," "He is in the house") follow the nominative, even when the sense is "The one who is in " the house, is there, is he" ; probably this is due to the fact that a prepositional or adverbial phrase always appears of subsidiary importance, and therefore is not allowed to occupy the position of honour. It would be interesting to investigate the reasons why (1) deictic or demonstrative words, (2) interrogative words; and (3) personal pronouns tend, as they undoubtedly do, to push their way to the beginning of sentences. In the case of (1) I fancy the sulution has something to do with gesture; in the case of (2) a powerful factor seems to have been the desire to reserve to the interrogative word the same position as the corresponding word in the answer will occupy, e.g., "Who did it?' 'He did it'; Egypt., 'He went away on account of what ?'; in the case of (3) it would not be surprising if pure egoism lay at the root of the usage. I throw out these remarks as examples of some topics that call urgently for investigation along comparative lines.

$$
\left[\begin{array}{ll}
6 & 6
\end{array}\right]
$$


It is thus clear that the Inswich specimen may be regarded as a cinerary urn, and it seems probable that the Brantham example had a similar use. So far as can be gathered, urns of this particular form and ornamentation are not common in this country, but Mr. Reginald Smith informs me in a letter that a specimen of very similar appearance to those here described, but differing from them in having an arcaded arrangement of the indentations above the band, is described in Trans. Essex Archeological Society, New Series, Vol. IV, 18. The Brantham urn is $17 \frac{1}{2}$ ins. high, and the photograph accompanying this note has been forwarded to me by Sir Hercules Read. The Ipswich specimen is 13 ins. bigh, $12 \frac{3}{4}$ ins. wide at the mouth, the lip is $\frac{5}{8}$ in. thick, and the moulding or band projects to the extent of

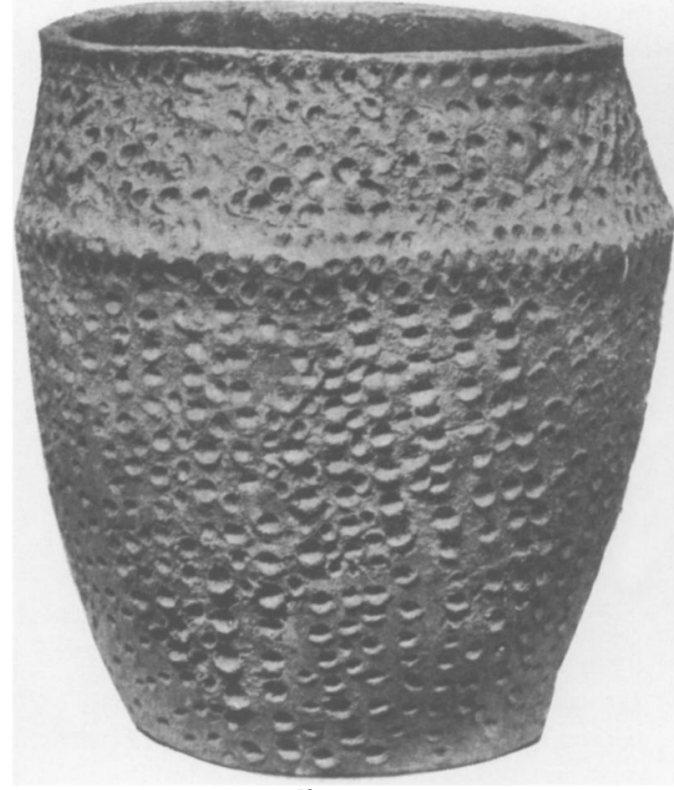

FIG. 1.

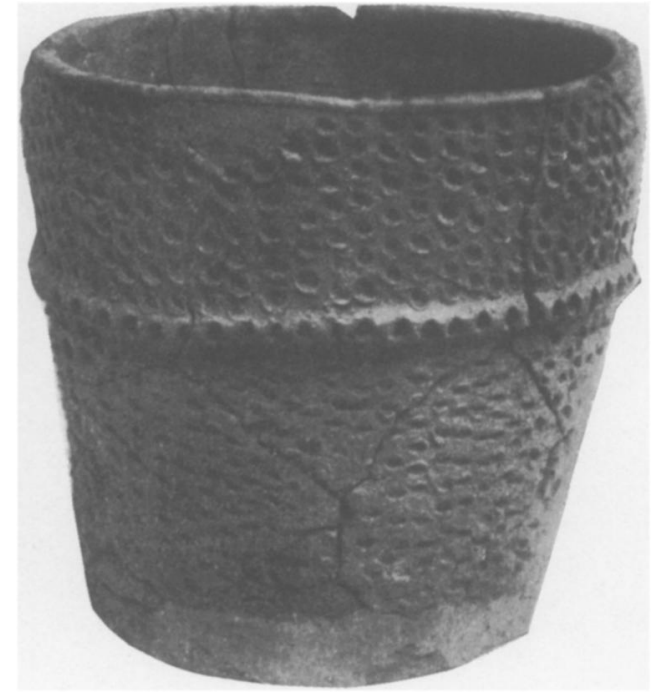

FIG. 2.

Two LATE BRONZE AGE URNS FROM EAST ANGLIA.

$\frac{1}{2}$ in. I am indebted to Mr. Frank Woolnough, Curator of the Ipswich Museum, for the photograph of the urn found near Hadleigh Road.

J. REID MOIR.

\section{Linguistics.}

Breton.

\section{Notes on Pokomchi (Guatemala). By A. C. Breton.}

The following extracts are translated literally from the Spanish-Latin and Pokomchi manuscript vocabulary of the seventeenth century in the museum library of the University of Pennsylvania at Philadelphia. About 300 Latin adverbs, prepositions, etc., are treated in the fragment remaining of that section, and Iuxta is a fair specimen, though some others have more phrases from the Vulgate, of ten with two or three versions in Pokomchi. There are 270 Pokomchi verbs in the general vocabulary and in the section on Pokomchi nouns, also equivalents in Pokomcbi for 260 Spanish verbs. Herewith is a small portion of an Abstract which I have condensed from the verbs.

Although the manuscript is only a fragment of the original works, it will be seen how much valuable information can be obtained from it, representing as it does the earliest form of this language known to the Spanish missionaries. The priest-author constantly quotes from the writings of Padre Francisco de Viana, who died in 1600 , and the document is an autograph, carefully written, but with the 